合成

有機合成化学工業の進歩発展と共に, 合成樹脂及び プラスチックスの生産は非常に盛大となり, 各種の成 型品及び工業材料としてその特長を利用されて極めて 幅の広い需要を得るに至った。従って従来天然産原料 で構成されている塗料工業には多くの影響を与兄, 合 成樹脂, 合成乾性油等の利用に上って各種の用途に応 じる合成樹脂塗料を供給し，その進歩発展は著しいる のがある。合成樹脂について述べるに当り, 昭和32年 1 月の全プラスチックス月産額を掲げて参考にする。 この表の数值によって, 現在我国で国産される合成樹 脂の種類と数量が䄮わかりのことと思う。

昭和 32 年度塗料生産計画と参照すると, 塗料に用 いられる合成樹脂はまだ少いと思う。さらに合成樹脂 の主なるものの性能及び特長, 用途を表に示して参考 にする。

1. 合成樹脂生産実績 (1957〜1月) (プラスチック 協会)

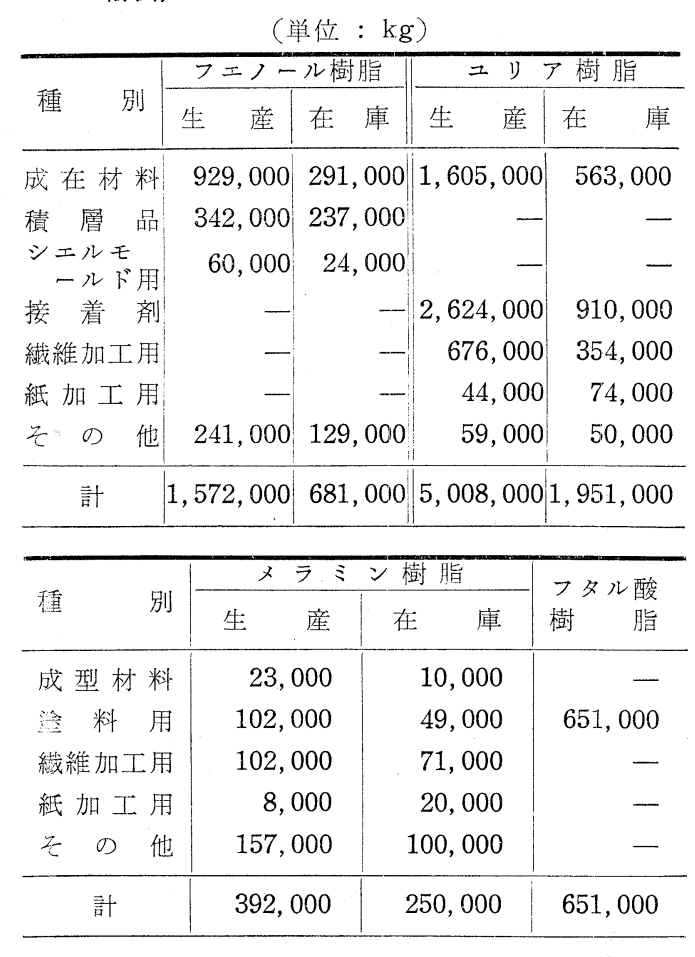

* 色材協会理事 東京都立工業奨励館
樹脂

667.621 .633

\begin{tabular}{|c|c|c|}
\hline \multirow{2}{*}{ 品 } & 1 & 月 \\
\hline & 生 & 在 \\
\hline イオン交換 樹脂 & - & 12,000 \\
\hline 不飽和ポリエステル & 201,000 & 159,000 \\
\hline け い 素 樹 脂 & 29,294 & 7,796 \\
\hline
\end{tabular}

塩化ビニル

\begin{tabular}{|c|c|c|}
\hline 会 社 名 & 工 場 & 月 \\
\hline 興 社 & 酒＼cjkstart田 & 253,640 \\
\hline 只 羽 化 成 & 錦 & 225,268 \\
\hline 大日本セルロイド & 新 井 & 5,800 \\
\hline 電 気 化 学 & 㗪 川 & 500,195 \\
\hline 日本カーバイト & 魚 津 & 676,599 \\
\hline 日 信 化 学 & 武 生 & 608,346 \\
\hline 日 本ゼオン & 蒲 原 & 701,192 \\
\hline " & 高 岡 & 119,375 \\
\hline 東 悪 合 成 & 名古屋 & 41,930 \\
\hline 三 井 化 学 & " & 368,310 \\
\hline モンサント化成 & 四日市 & 759,800 \\
\hline 鐘 淵 化 学 & 大 阪 & 983.039 \\
\hline 住 友 化 学 & 番 水 & 546,920 \\
\hline 新 日本空素 & 水 俣 & 651,671 \\
\hline 計 & & $6,992,085$ \\
\hline
\end{tabular}

塩化ビニリデン

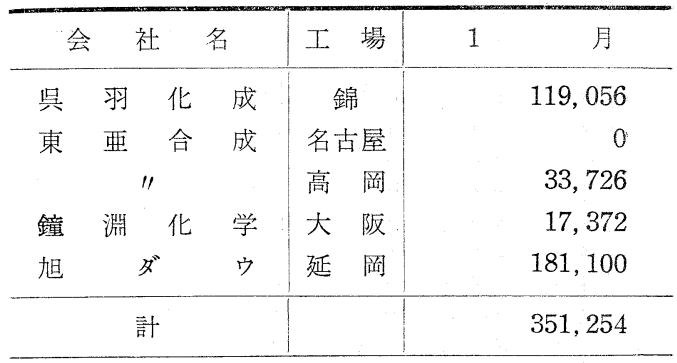

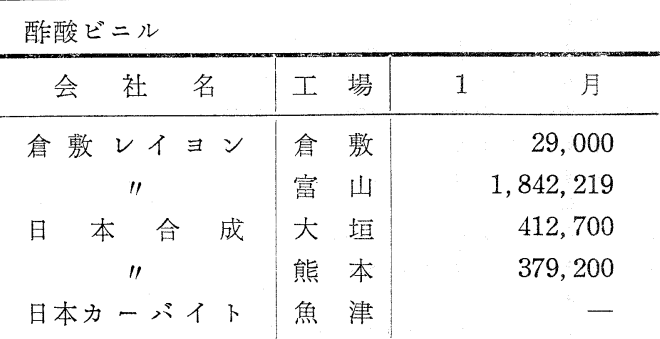




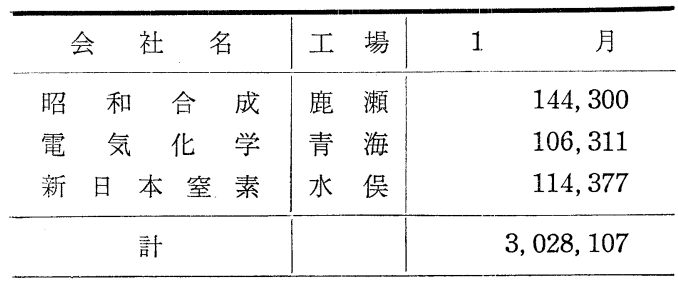

ポリビニルアルコール

\begin{tabular}{|c|c|c|}
\hline 会 社 名 & 工 場 & 月 \\
\hline 倉敷 レイヨン & 倉 敷 & 14,000 \\
\hline "I & 富 山 & 929,549 \\
\hline 日 本 合 成 & 大 垣 & 140,600 \\
\hline 11 & 熊 本 & 161,100 \\
\hline 大 同 化 成 & 大 阪 & 3,210 \\
\hline 日本カーバイト & 魚 津 & 一 \\
\hline 三菱 レイヨン & 大 竹 & 0 \\
\hline 鐘 淵 紡 績 & 淀 川 & 428 \\
\hline 積 水 化 学 & 大 阪 & 0 \\
\hline 計 & & $1,248,887$ \\
\hline
\end{tabular}

カプロラクタム

\begin{tabular}{|c|c|c|}
\hline 会 社 名 & 工 場 & 月 \\
\hline $\begin{array}{c}\text { 東洋 } レ ー ヨ ン \\
\prime \prime \text { (回 収) }\end{array}$ & $\begin{array}{c}\text { 名古屋 } \\
\prime \prime\end{array}$ & $1,597,800$ \\
\hline 東 亜 合 成 & " & 152,505 \\
\hline 宇 部 興 産 & 宇 部 & 265,430 \\
\hline 計 & & $2,015,735$ \\
\hline \multicolumn{3}{|l|}{ 酢酸繊維素 } \\
\hline 会 社 名 & 工 場 & 月 \\
\hline 新 日 本窒素 & 水 俣 & 101,020 \\
\hline 大日本セルロイド & 網 干 & 489,000 \\
\hline " & 新 井 & 0 \\
\hline 計 & & 590,020 \\
\hline
\end{tabular}

メタクリル酸樹脂

\begin{tabular}{|c|c|c|c|}
\hline \multirow{2}{*}{ 会 社 名 } & \multirow{2}{*}{ 工 場 } & 1 & 月 \\
\hline & & モノマー- & ポリマー \\
\hline 三菱レイヨン & 大 个 & 156,312 & 91,967 \\
\hline 藤 化 成 & 志 & 21,548 & 9,471 \\
\hline 武蔵野化学 & 荻 䇠 & 16,300 & - \\
\hline 計 & & 194,160 & 101,438 \\
\hline
\end{tabular}

2. 昭和 32 年度塗料生産計画 - 資材需給表 (日本塗料工業会)
(C)生産計画

（単位：トン）

\begin{tabular}{|c|c|c|c|}
\hline \multicolumn{2}{|r|}{ 品 種 別 } & 量 & $\%$ \\
\hline \multicolumn{2}{|c|}{ 油 性 㳂 料 } & 85,400 & 40.7 \\
\hline \multicolumn{2}{|c|}{ 酒 性 洷 料 } & 9,000 & 4. 3 \\
\hline \multicolumn{2}{|c|}{ 水 性 洷 料 } & 3,000 & 1.4 \\
\hline \multicolumn{2}{|c|}{ 電＼cjkstart絶＼cjkstart浍＼cjkstart料 } & 7,600 & 3.6 \\
\hline$\overline{7}$ & ッ カ & 18,000 & 8.6 \\
\hline & フェノール系 & 4,800 & 2.3 \\
\hline & アルキッド係 & 13,200 & 6.3 \\
\hline \multirow{2}{*}{ 成 } & メラミン系 & 12,000 & 5.7 \\
\hline & ユリア系 & 2,400 & 1.1 \\
\hline 樹 & 塩化ビニル系 & 5,400 & 2.6 \\
\hline 脂 & 酢酸 ビニル孫 & 4,200 & 2.0 \\
\hline 塗 & エトキシリン预 & 1,200 & 0.6 \\
\hline \multirow{2}{*}{ 料 } & そ の 他 & 1,200 & 0.6 \\
\hline & 計 & 44,400 & 21.2 \\
\hline シ & ンナー 一 他 & 42,600 & 20.2 \\
\hline & 計 & 210,000 & 100.0 \\
\hline
\end{tabular}

主要合成樹脂一覧表

\begin{tabular}{|c|c|c|c|}
\hline & 封 脂 名 & 徵 & 用 \\
\hline & $\mid \begin{array}{l}フ \text { 樹 } \\
\text { 脂 }\end{array}$ & $\begin{array}{l}\text { 強度優秀, 暗色, 電 } \\
\text { 気絶縁性, 酎酸性耐 } \\
\text { 熟性, 耐水性何れ\& } \\
\text { 良好, 耐アルカリ性 } \\
\text { 弱い, }\end{array}$ & $\begin{array}{l}\text { 電気絶縁材料, 耐 } \\
\text { 酸器具, 食器, 機 } \\
\text { 械部品塗料 }\end{array}$ \\
\hline 硬 & ユリア樹脂 & $\begin{array}{l}\text { 無色にして着色自由 } \\
\text { 大体フエノ樹脂 } \\
\text { の性質に類似するが } \\
\text { 耐水性やや弱く老化 } \\
\text { 性むり }\end{array}$ & 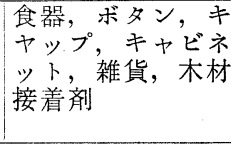 \\
\hline 七 & $\begin{array}{l}\text { メラミン樹 } \\
\text { 脂 }\end{array}$ & $\begin{array}{l}\text { ユリア樹脂に殆えぞ } \\
\text { 似ているが，硬度大 } \\
\text { だ，耐水性む良好 }\end{array}$ & $\begin{array}{l}\text { 化粧板, 食器, 電 } \\
\text { 気部品, 織物や紙 } \\
\text { の樹脂加工 }\end{array}$ \\
\hline 性 & $\begin{array}{l}\text { 不飽和汴り } \\
\text { エステル樹 } \\
\text { 脂 }\end{array}$ & 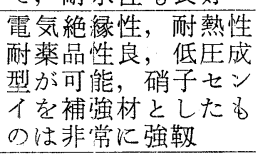 & $\begin{array}{l}\text { 軽金属代用構造材 } \\
\text { 料, 車輛, 自動車 } \\
\text { 船舶, 建築材料, } \\
\text { 封入注型品 }\end{array}$ \\
\hline 部 & 珪 素 樹 脂 & $\begin{array}{l}\text { 高, 低温に耐え, 電 } \\
\text { 気絶縁性, 撥水性良 } \\
\text { 好, 高価 }\end{array}$ & 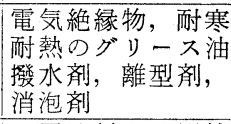 \\
\hline & $\begin{array}{l}\text { エポキ シ } \\
\text { 樹 } \\
\end{array}$ & $\begin{array}{l}\text { 金属接着性大, 耐薬 } \\
\text { 品性良, やや高価 }\end{array}$ & $\begin{array}{l}\text { 金属塗料, 金属接 } \\
\text { 着娍 }\end{array}$ \\
\hline & $\begin{array}{l}\text { 塩 } \\
\text { 化 } \text { 樹 }\end{array}$ & 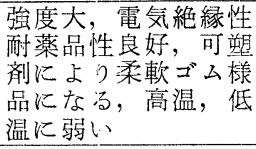 & 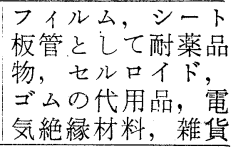 \\
\hline & $\begin{array}{l}\text { 塩化ビニリ } \\
\text { デン樹脂 }\end{array}$ & 塩ビより耐薬品性大 & $\begin{array}{l}\text { 塗料 (耐磨耗シー } \\
\text { 下カバー金網代 } \\
\text { 用, 品耐薬品用成 } \\
\text { 型品 }\end{array}$ \\
\hline
\end{tabular}




\begin{tabular}{|c|c|c|c|}
\hline & & 徵 & 用 \\
\hline \multirow{3}{*}{ 槷 } & 朘ビニル & $\begin{array}{l}\text { 透明, 接着性大, } \\
\text { 容剂に可溶, 耐 } \\
\text { 泛しい }\end{array}$ & $\begin{array}{l}\text { 塗料, 点出し塗料, } \\
\text { 接着凨, ビニロン } \\
\text { 原料 }\end{array}$ \\
\hline & ニルアル & 熱, 水に可溶 & $\begin{array}{l}\text { ビニロン, アセタ } \\
\text { ールの原料, 乳化 } \\
\text { 剤 }\end{array}$ \\
\hline & $\begin{array}{l}\text { ルエー } \\
\text { 樹脂 }\end{array}$ & \begin{tabular}{|l|} 
無色透明, 密着性良 \\
L, 各種溶剤飞可溶
\end{tabular} & $\begin{array}{l}\text { 可ソ剤, 接着剂, } \\
\text { 塗料 }\end{array}$ \\
\hline \multirow[t]{2}{*}{ 可 } & $\begin{array}{l}\text { ニルアセ } \\
\text { ール樹脂 }\end{array}$ & 無色，透明，密着性 & $\begin{array}{l}\text { フイルム, 安全硝 } \\
\text { 子中間膜, 接着剤, } \\
\text { 塗料 }\end{array}$ \\
\hline & $\begin{array}{lll}\text { メタアク } \\
\text { ル } \\
\text { ル }\end{array}$ & \begin{tabular}{|l|l} 
無色透明, 強鞋, 耐 \\
薬品性もかなり大
\end{tabular} & $\begin{array}{l}\text { 風防硝子, 広告装 } \\
\text { 飾, 雑貨, 医療品 }\end{array}$ \\
\hline 塑 & 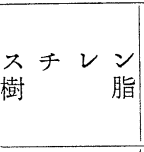 & $\begin{array}{l}\text { 無色透明, 電気絶縁 } \\
\text { 性, 耐水性, 耐薬品 } \\
\text { 性大, 失透性有り }\end{array}$ & $\begin{array}{l}\text { 射出成型による高 } \\
\text { 周波絶縁物及び食 } \\
\text { 器, 玩具, 雑貨, } \\
\text { ラジオ部品, 発泡 } \\
\text { 材 }\end{array}$ \\
\hline 性 & 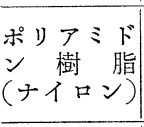 & $\mid$ & $\begin{array}{l}\text { 合成センイ以外に } \\
\text { 成型物として小型 } \\
\text { 崡車等の耐磨耗用 } \\
\text { 品 }\end{array}$ \\
\hline 樹 & ポリエチレ & $\begin{array}{l}\text { 水より軽い, 柔軟, } \\
\text { 耐熱性に之しい, 耐 } \\
\text { 薬品性,電気絶緣性, } \\
\text { 耐水性非常に良好 }\end{array}$ & $\begin{array}{l}\text { 電線被覆, 電波機 } \\
\text { 器用品, 瓶, 包装 } \\
\text { 材料, フィルム }\end{array}$ \\
\hline \multirow[t]{3}{*}{ 脂 } & 弗 素 樹 脂 & $\begin{array}{l}\text { 低温及び高温の広範 } \\
\text { 围電気絶縁性, 酎 } \\
\text { 薬品性強度非常に大 } \\
\text { 高価 }\end{array}$ & $\begin{array}{l}\text { 高度電気絶縁材料 } \\
\text { 耐薬品物, パッキ } \\
\text { ング, ライニング }\end{array}$ \\
\hline & $\begin{array}{l}\text { 綫維素プラ } \\
\text { スチックス } \\
\end{array}$ & $\begin{array}{l}\text { 透明, 可撓性, 加工 } \\
\text { 性良好 }\end{array}$ & 難燃性セルロイト \\
\hline & \begin{tabular}{lll|} 
カ & 樹 & 脂 \\
& &
\end{tabular} & $\begin{array}{l}\text { 手触り，音響など動 } \\
\text { 物の角に似いる深 }\end{array}$ & $\begin{array}{l}\text { ボタン, 装身具, } \\
\text { ペン軸 }\end{array}$ \\
\hline
\end{tabular}

合成樹脂塗料

1.フェノール樹脂塗料

今日の合成樹脂塗料の先軀をなすものである。最近 にはアルキルフェノール樹脂の発達がみられ, 従来こ の系統のワニスの欠点であった着色, 変色がなくなり, 本来の長所である速乾性, 耐薬品性, 機械的強度, 電 気的絶縁性が生かされて今後も発展する。

フェノールル樹脂塗料は単に溶剤にとかしたもの と，乾性油と混溶したものとある。

1.1 アルコール可溶性フェノール樹脂塗料

(1) 常温乾燥性ノボラック型

（2）加熱乾燥性レゾール型

1.2 油溶性フェノール樹脂塗料

（1）ロジン，エステルグム変性フェノール樹脂 亜麻仁油, シナキリ油等と組合せて, 乾燥性, 耐 久性よし。

（2）脂肪酸変性フェノール樹脂

主として亜麻仁油, キリ油脂肪酸で変性し, 焼付 用に作り，弾性耐薬品性に富も。

（3）アルキド樹脂変性フェノール樹脂
（4）アルキルフェノール樹脂

所謂 $100 \%$ フェノール樹脂という。ワニスにする 場合にはやはり，シナキリ油，亜麻仁油等と融合 して用いる。一般的欠点である着色が少く, 酎候 性よい。tーブチルフェノール，t-アミルフェノー ル，フェニルフェノール等とホルマリンと縮合し てつくられる。

（5）その他変性フェノール樹脂

フェノールフルフラール樹脂, ブチラール樹脂変 性フェノール樹脂さらにエポキシ樹脂等

2. アルキッド樹脂塗料

塗料用アルキッド樹脂を大別する。

（1）乾性油変性アルキド樹脂

（2）不乾性油変性アルキド樹脂

（3）ロジン変性アルキド機脂

（4）フェノール樹脂変性アルキド樹脂

（5）スチレン化アルキド樹脂

（6）シリコン樹脂変性アルキド樹脂

（7）エポキシ樹脂変性アルキド樹脂

最近これ等は非常に進歩した㙦料であって，特長 として硬度高く，可撓性優れ，金属との接着性，耐 薬品性は数段とよくなって扣り, 今後大いに期待さ れる。

3. 尿素, メラミン樹脂塗料

（1）水溶性尿素樹脂塗料

（2）酒精溶性尿素樹脂塗料

（3）焼付用尿素樹脂及びメラミン樹脂塗料

尿紊一ホルマリン,またはメラミンホルマリンの反 応によって出来るメチロール化合物をブチルアルコ ールでエーテル化して塗料用とし，他方アルキド樹 脂と相溶させて作る。

この系統の塗料は赤外線を使用する焼付方法の発 展により，流れ作業方式による金属製品の塗装に好 適なるため広く使われる（自動車，オートバイ，冷 蔵庫, 扇風機, ミシン等々)

4. ビニル樹脂系塗料（塩化ビニル樹脂, 酢酸ビニル 樹脂の外にメタクリル樹脂, 塩化ビニリデン樹脂等 含も)

4.1 塩化ビニル樹脂塗料

4.2 塩化ビニル酢酸ビニル共重合樹脂塗料

塩化ビニル 85-酢酸ビニル 15 系

塩化ビニル 70-酢酸ビニル30 系

平均重合度 $100 \sim 500$ 位のものが多い。

塩化ビニル系樹脂の特長である耐薬品性がよい。

しかし他の樹脂特に油変性アルキド樹脂との相溶性 
のよいものが希望される。

4.3 メタクリル酸エステル，アクリル酸エステル樹 脂塗料

4.4 酢酸ビニル樹脂塗料

酢酸ビニル樹脂自体は無色透明であるが耐水性, 耐熱性は良好ではない。然し低重合度の樹脂は塗料 用として一部使用され, 硝化綿と相溶してラッカー に使用される。

最む多いのは酢酸ビニルモノマーをポリビニルア ルコールを含む水溶液の中で乳化重合させ，体質， 顔料と組合せてェマルション塗料として室内用塗料 として多く使用される。

5. スチレン系樹脂塗料

5.1 ラテックス形塗料

\section{2 溶液型塗料}

塗料用スチレン樹脂は無色透明, 耐酸, 耐アルカ

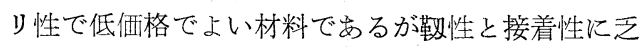
しい。最近これによく相溶する接着性の極めてすぐ れたポリビニルメチルェーテル樹脂 (PVM) が国産 されたのでこれと相溶したものは優秀なるワニスと なり，今後が大いに期待される。

5.3 スチレン化油, スチレン化アルキド樹脂塗料

乾性油はスチレン化によって速乾性と耐候性が与 えられまたアルキド樹脂は性能向上する。

6. 不飽和ポリエステル樹脂塗料

不飽和ポリエステルをスチレンなどのモノマーに溶
解した液状の物質で触媒及び促進剤の使用によって常 温に於て硬化して樹脂物質を形成する。強化プラスチ ックス用樹脂として代表的なもので積層用樹脂として の特質が，塗料に於ける無溶剤ワニスとして利用が可 能である。従来の塗料と代った所を見ると (1) 常温に て液状，(2) 溶剤としててはスチレン等のビニル系モノ マーを用い。(3) 硬化に際し, 全部塗膜成分になる。

（4）有機過酸化物等を触媒に用いる。(5) 硬化は発熱 反応である。(6) 触媒, 促進剤を添加したものは一定. の可使用時間があること, (7) 厚塗が出来て, 肉ヤセ の少いこと。

パテ用, 木部塗装用, ライニング等今後発展する。

7. エポキシ樹脂塗料

EPON, Araldite 等塗料用樹脂がある，ビスフェノ 一ルAとエピクロルヒドリンの縮合生成物で，揮発性 物質を生ずることなく熱硬化し，収縮率少く，物理的 及び化学的性質優秀, 金属への接着性は極めて優秀で ある。脂䏳酸で一部ェステル化して変性も出来, 塗料 及び接着剤として, 従来のアルキド樹脂に勝るものと してて期待されている。

8. その他の塗料用合成樹脂

シリコン樹脂塗料, 弗素樹脂塗料, ポリウレタン系 塗料, チタン酸エステル塗料, フラン樹脂塗料, 等女. り, 今後新しいプラスチックス材料の発展と共に進歩: すると思ら。 


\begin{tabular}{|c|c|c|c|c|c|c|c|c|c|c|c|c|c|c|c|c|c|c|c|c|c|}
\hline & 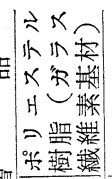 & $\begin{array}{l}r \\
\text { ì } \\
\text { Lे } \\
\text { - } \\
-i\end{array}$ & 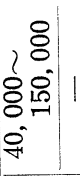 & 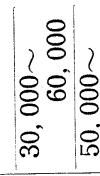 & & $\begin{array}{l}\stackrel{2}{2} \\
\text { ? } \\
\text { S }\end{array}$ & 1 & ? & 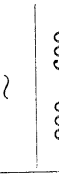 & 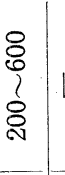 & 111 & 1 & 1 & 1 & $\begin{array}{ll}0 & 15 \\
0 & 7 \\
i & 1 \\
0 & 3\end{array}$ & 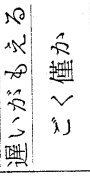 & & 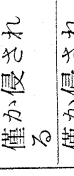 & 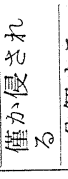 & 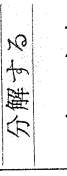 & 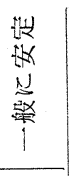 \\
\hline & 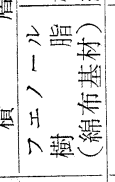 & $\begin{array}{l}10 \\
-i \\
\text { Lి } \\
m \\
-i\end{array}$ & $\mid$\begin{tabular}{c|}
0 \\
2 \\
8 \\
8 \\
8 \\
0 \\
0
\end{tabular} & 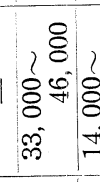 & & $\begin{array}{l}\text { r. } \\
\text { oे } \\
0\end{array}$ & 18 & 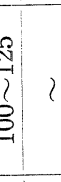 & & 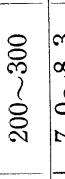 & 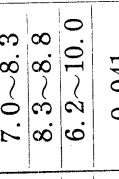 & $\begin{array}{l}F \\
0 \\
0\end{array}$ & $\begin{array}{l}8 \\
0 \\
i \\
0 \\
0\end{array}$ & $\begin{array}{l}\dot{1} \\
\dot{0} \\
\dot{i} \\
\dot{0} \\
\dot{0}\end{array}$ & $\begin{array}{l}0 \\
\dot{1} \\
\text { iे } \\
0 \\
\dot{-i}\end{array}$ & 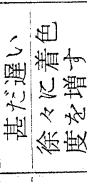 & 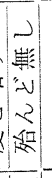 & $\underset{f}{a j}$ & 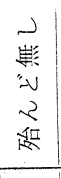 & 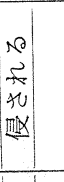 & 进 \\
\hline & 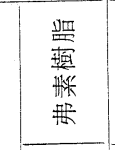 & $\begin{array}{c}\infty \\
i \\
i \\
i \\
i\end{array}$ & 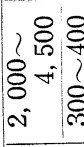 & $\begin{array}{l}8 \\
\vdots \\
\vdots \\
\vdots\end{array}$ & & $\stackrel{\circ}{+}$ & 1 & $\stackrel{0}{0}$ & & 品 & \begin{tabular}{c|c|c}
0 & 0 & 0 \\
$i v$ & $\dot{v}$ & $\hat{N}$
\end{tabular} & 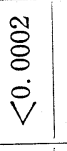 & $\begin{array}{l}\tilde{O} \\
\dot{8} \\
\dot{\nabla}\end{array}$ & $\begin{array}{l}8 \\
0 \\
0\end{array}$ & 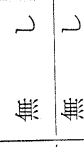 & 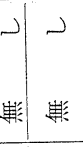 & 靵: & \lrcorner & \begin{tabular}{c|}
$\sim$ \\
蝗
\end{tabular} &. & 鞦 \\
\hline & $\begin{array}{l}\lambda \\
\vec{y} \\
H \\
H \\
\Rightarrow \\
\text { \%ै }\end{array}$ & $\begin{array}{l}\mathscr{8} \\
\dot{0} \\
i \\
\text { ô } \\
\dot{0}\end{array}$ & $\begin{array}{ll} & 8 \\
1 & 8 \\
8 & 0 \\
8 & 0 \\
8 & 0 \\
-1 & 10\end{array}$ & $\begin{array}{l}2 \\
1 \\
15 \\
12\end{array}$ & & $\stackrel{m}{\wedge}$ & $1 \%$ & $\stackrel{\circ}{0}$ & & 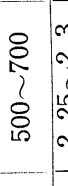 & 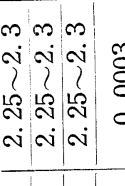 & $\begin{array}{l}\dddot{8} \\
8 \\
\dot{0}\end{array}$ & $\begin{array}{l}\text { ஜ } \\
8 \\
0 \\
\dot{0}\end{array}$ & $\begin{array}{l}0 \\
0 \\
0 \\
0\end{array}$ & \begin{tabular}{l|l}
$\overrightarrow{0}$ & \multicolumn{3}{|}{} \\
$\dot{0}$ &
\end{tabular} & 连 & 朝 & $\sim$ & 籍 & 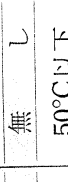 & 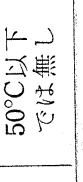 \\
\hline & 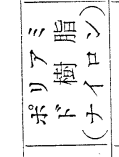 & $\vec{I}$ & 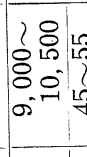 & 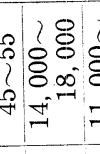 & $\begin{array}{ll}3 & 8 \\
5 & 8 \\
5 & 0 \\
-1 & \end{array}$ & $\begin{array}{l}0 \\
- \\
\infty \\
\infty \\
0\end{array}$ & 1 & $\mid \begin{array}{l}0 \\
0 \\
0 \\
0 \\
0 \\
0 \\
0\end{array}$ & & 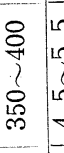 & 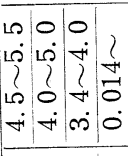 & $\begin{array}{ccc}2 & 0 \\
2 & 0 \\
4 & 0 & ? \\
0 & 0 \\
0 & 0 \\
0 & 0 \\
0\end{array}$ & 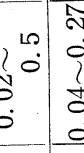 & $\begin{array}{l}\hat{N} \\
0 \\
i \\
\vdots \\
0 \\
\dot{0}\end{array}$ & 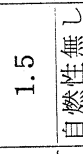 & 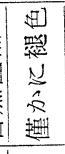 & 题 & 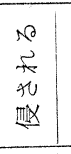 & $\begin{array}{c}\sim \\
\text { 判 }\end{array}$ & 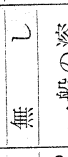 & 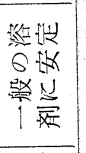 \\
\hline & 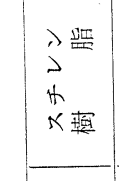 & $\begin{array}{c}\infty \\
0 \\
-i \\
+ \\
0 \\
\\
\\
\end{array}$ & $\begin{array}{ll}8 & 0 \\
2 & 0 \\
8 & 0 \\
8 & 1 \\
m & 1\end{array}$ & 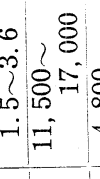 & & $\begin{array}{l}0 \\
i \\
\text { ?े } \\
\stackrel{1}{0} \\
0\end{array}$ & 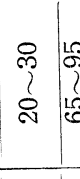 & 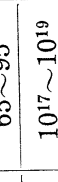 & & 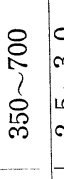 & 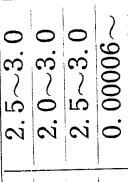 & 20 & $\begin{array}{l}\text { lo } \\
\text { ठ̊े } \\
0 \\
\dot{0}\end{array}$ & 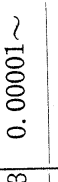 & 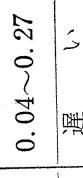 & 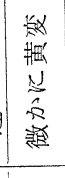 & 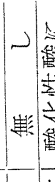 & 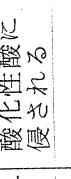 & ○, & 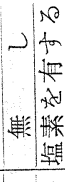 & 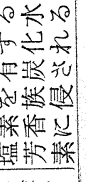 \\
\hline & 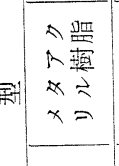 & $\begin{array}{l}\text { ô } \\
+1 \\
\text { ? } \\
0 \\
- \\
\end{array}$ & $\mid \begin{array}{ll}3 & 8 \\
8 & 8 \\
8 & 15 \\
0 & 15 \\
0 & 0\end{array}$ & $\begin{array}{ccc}10 & 1 & 8 \\
1 & 8 & 8 \\
8 & 8 & 10 \\
-1 & 9 \\
-1 & 9\end{array}$ & \begin{tabular}{ll|}
2 & 8 \\
8 & 8 \\
8 & 0 \\
$9^{-1}$ &
\end{tabular} & $\begin{array}{l}+1 \\
\dot{0} \\
i \\
0 \\
0\end{array}$ & $\begin{array}{ll}0 & 0 \\
0 & 1 \\
0 & 7 \\
-1 & 10\end{array}$ & 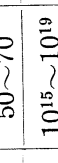 & & 8 & 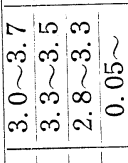 & 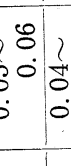 & $\begin{array}{l}5 \\
2 \\
2 \\
0 \\
0 \\
0\end{array}$ & 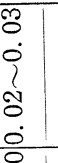 & \begin{tabular}{l|l}
10 & 5 \\
0 & 5 \\
0 & \\
0 & \\
0 & 糟
\end{tabular} & 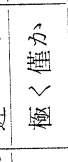 & & 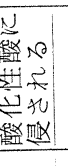 & \begin{tabular}{l|}
$\sim$ \\
粠
\end{tabular} & & 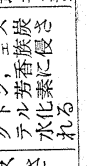 \\
\hline & 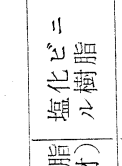 & $\begin{array}{c}0 \\
\dot{i} \\
2 \\
i \\
-i\end{array}$ & $\begin{array}{ll}1 & 8 \\
8 & 8 \\
80 & 0 \\
i & 1\end{array}$ & 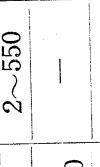 & 1 & 1 & 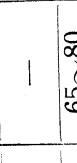 & $\begin{array}{ll}0 & 0 \\
0 & 0 \\
l & 0 \\
0 & 0 \\
0 & 0 \\
0\end{array}$ & & 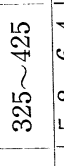 & 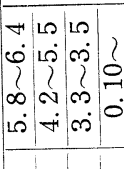 & 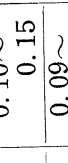 & $\begin{array}{ll}0 & 0 \\
2 & 0 \\
0 & 0 \\
0 & 0 \\
0 & 0 \\
0 & 0 \\
0\end{array}$ & $\begin{array}{l}0 \\
\dot{0} \\
\dot{0} \\
1 \\
8 \\
0 \\
0\end{array}$ & 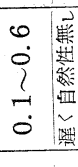 & $\hat{x}$ & $\nu$ & 㳦 & 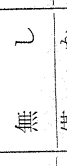 & 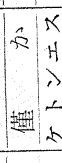 & 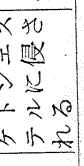 \\
\hline & 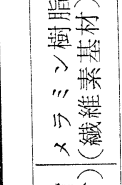 & 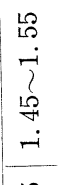 & $\mid \begin{array}{l}8 \\
2 \\
8 \\
8 \\
0 \\
0 \\
n\end{array}$ & 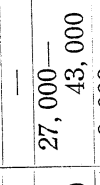 & 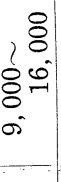 & 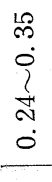 & $1 £$ & $\begin{array}{l}\stackrel{2}{0} \\
\text { ? } \\
\text { ? } \\
0\end{array}$ & $\begin{array}{l}0 \\
0 \\
0 \\
0 \\
0 \\
0\end{array}$ & 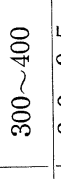 & 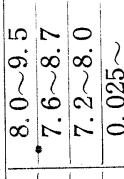 & 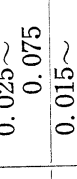 & 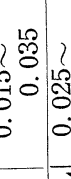 & $\begin{array}{ll}3 & \frac{1}{9} \\
3 & 0 \\
0 & 0 \\
0 & 0 \\
0\end{array}$ & $\begin{array}{l}0 \\
\dot{0} \\
\dot{l} \\
\dot{0}\end{array}$ & 趣 & 嗐 & 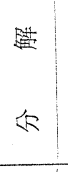 & 紫: & 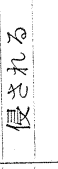 & 厥 \\
\hline & 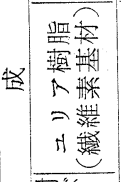 & 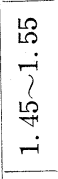 & $\mid \begin{array}{l}8 \\
2 \\
8 \\
8 \\
8 \\
0 \\
0 \\
0\end{array}$ & $\mid \begin{array}{c}8 \\
2 \\
1 \\
80 \\
80 \\
10 \\
10\end{array}$ & $\begin{array}{l}8 \\
2 \\
2 \\
8 \\
8 \\
8 \\
0 \\
0 \\
0 \\
-1\end{array}$ & $\begin{array}{l}0 \\
\infty \\
0 \\
? \\
\text { ? } \\
0 \\
0\end{array}$ & 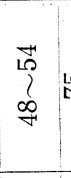 & 党 & 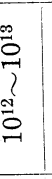 & 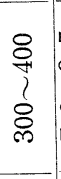 & 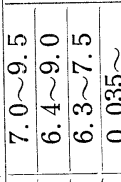 & 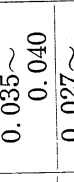 & $\begin{array}{l}2 \\
2 \\
\text { i. } \\
0 \\
0 \\
0 \\
0\end{array}$ & $\begin{array}{l}0 \\
\dot{0} \\
i \\
\hat{0} \\
0 \\
\dot{0}\end{array}$ & 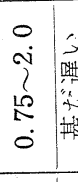 & 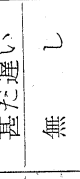 & 嗍 & 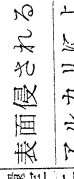 & 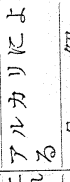 & K & 挷 \\
\hline & 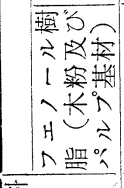 & 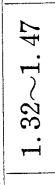 & $\begin{array}{l}8 \\
10 \\
0 \\
2 \\
8 \\
8 \\
10\end{array}$ & 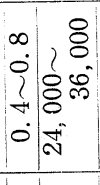 & $\begin{array}{l}2 \\
2 \\
2 \\
8 \\
8 \\
0 \\
0\end{array}$ & $\begin{array}{l}R \\
0 \\
i \\
\text { d } \\
0 \\
0\end{array}$ & 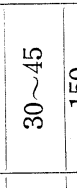 & & $\begin{array}{l}\text { 울 } \\
\text { ? } \\
\text { oे }\end{array}$ & & 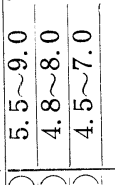 & $\begin{array}{l}2 \\
0 \\
0 \\
i \\
0 \\
0 \\
0\end{array}$ & $\begin{array}{l}0 \\
\stackrel{1}{0} \\
\dot{0} \\
\text { oे } \\
\dot{0}\end{array}$ & $\begin{array}{l}8 \\
\dot{0} \\
\text { ?े } \\
\text { Oे } \\
\dot{0}\end{array}$ & \begin{tabular}{c|c}
0 & 1 \\
$\dot{2}$ & \\
0 & 4 \\
0 & 4 \\
0
\end{tabular} & 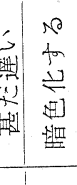 & 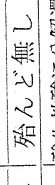 & 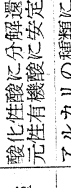 & 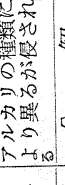 & \& & 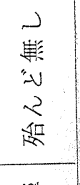 \\
\hline & & 纽 & 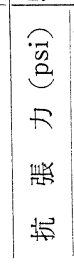 & 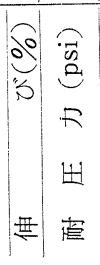 & 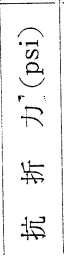 & 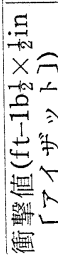 & $\frac{\alpha}{20}$ & 寉采 & 要 & 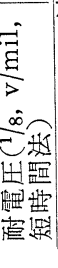 & 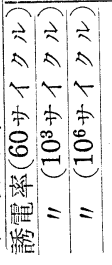 & 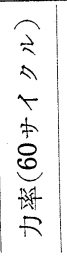 & 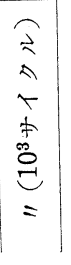 & 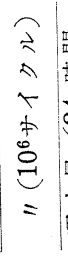 & 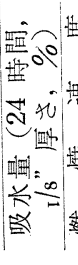 & 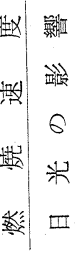 & 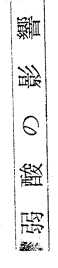 & 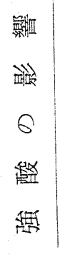 & 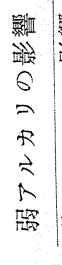 & | & 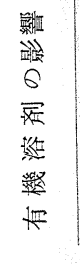 \\
\hline
\end{tabular}

